\title{
Coastal Erosion and the Promontory Fort: Appearance and Use during Late Iron Age and Early Medieval County Waterford, Ireland
}

\author{
Edward Pollard *, Anthony Corns ${ }^{\circledR}$, Sandra Henry and Robert Shaw ${ }^{\circledR}$ \\ The Discovery Programme, Centre for Archaeology and Innovation Ireland, 6 Mount Street Lower, \\ 2 D02 T670 Dublin, Ireland; anthony@discoveryprogramme.ie (A.C.); sandra@discoveryprogramme.ie (S.H.); \\ robert@discoveryprogramme.ie (R.S.) \\ * Correspondence: edward@discoveryprogramme.ie; Tel.: +353-1-639-3724
}

Received: 7 May 2020; Accepted: 14 July 2020; Published: 18 July 2020

check for updates

\begin{abstract}
Promontory forts are an understudied but distinctive maritime archaeological feature from the Iron Age to the early medieval period from northern Spain to Scotland. Their coastal location renders them susceptible to erosion and loss to history, a situation exacerbated by increased storm frequency and sea level rise. Reconstruction of their original form is important to determine their role in the society of the time. This paper concentrates on a particularly notable group of promontory forts along the Copper Coast of Co. Waterford, where traces of up to 32 remain today within a $24 \mathrm{~km}$ stretch of coastline. The methodology has involved using oral tradition, historical records and field survey. This has been enhanced by aerial survey using drones and light aircraft. This paper models the data to estimate areas eroded and show how forts were once significantly larger and dominated coastal resources with an economy of farming, fishing, mining and trading. This paper calculates a likely erosion rate of $4-5 \mathrm{~cm} / \mathrm{yr}$ and anticipates the last remains to be lost in 350 years, perhaps sooner with climate change.
\end{abstract}

Keywords: climate change; oral tradition; medieval coastline; aerial archaeology; mining; Celtic Sea

\section{Introduction}

Anthropogenic climate change is a growing global threat to cultural heritage worldwide [1]. Therefore, an urgency to conduct coastal investigations is underlined by both the continuance of erosional processes in a context of climate projections in Ireland that indicate an increased frequency of storm surge events and heights, with the global mean sea level rising at $3 \mathrm{~mm} /$ year since 1993, while models project a rise in sea level over the 21st century up to $2.5 \mathrm{~m} \mathrm{[2,3].} \mathrm{Previous} \mathrm{historical} \mathrm{work}$ on coastal erosion has looked at the early images and maps of the coast to determine the accuracy of this evidence, the rates of change and the extent of erosion along the coast [4]. The study of historical maps shows improved survey accuracy within the last couple of centuries but many sites were only surveyed at a small scale. Improvements in aerial survey and remote sensing can show more recent differences but understanding the extent of change over longer periods is more complicated and research has relied on the preservation of sea level markers from palaeoenvironmental and archaeological material after sea level rise and associated flooding [5].

There have been several studies on the vulnerability of archaeological heritage to erosion (e.g., recording threats to a standing stone or palaeosol, [6,7]). However, attempts to reconstruct the geomorphology around eroding sites have mostly looked at reconstructing sea level during lower or higher stages during prehistoric periods, or during the last few centuries from paintings or photographs $[8,9]$. In 1917, the village of Hallsands in Devon was eroded after shingle offshore was 
dredged [4] (p. 35). Few have looked at more long-term change over the last two millennia, where headlands and bays would still have been under continual change after less dramatic changes in sea level. For example, aerial photography and historic mapping suggest that $25 \%$ of the eroding four-banked ringfort of Cahermore at Carrowhubbuck North in Co. Sligo has been lost since 1910 [10]. This normally circular Iron Age to early medieval type of settlement is shown in the early 19th-century Ordnance Survey (OS) as D shaped, indicating that part had already been eroded away. A study of Cretaceous chalk cliff retreats in East Sussex modelled a 2-6 cm/yr loss through the Holocene, though the authors believed this had increased more recently from human intervention and higher wave energy [11]. In Ireland, the CHERISH project has been gathering baseline data on the present erosion of archaeological sites during fieldwork so future collapse can be measured accurately. Further, archival data has been collected that refers to areas of erosion, which, although not as accurate as modern remote sensing, can lead to information on the importance of sites, as they may have looked significantly different to today. It is also possible to take the evidence of coastal erosion further back in time, determining erosion rates by looking at uneroded monuments for comparison.

One notable construction that is particularly vulnerable to eventual total loss consequent upon its unique form and coastal location is the promontory fort. Promontory forts, though previously under researched, are common archaeological sites located above the cliffs around the Irish and Celtic Seas, linking these areas in a historic maritime culture with Britain and beyond. For the archaeologist to understand how these sites were used, the task is made more difficult by their exposure to approximately 1500-2000 years of erosion since they were first constructed. As the present coastal cliffs of northern Europe have been exposed to sea erosion since the last Ice Age, the extent of coastal change is difficult to determine, being dependent on factors such as aspect, weather patterns, physical structure, rock type and human modification. This paper concentrates on a specific group of Iron Age to early medieval promontory forts situated on the Co. Waterford coast of Ireland which are particularly vulnerable to the elements.

This study aims to determine what has already been lost and estimates the lifespan of what remains. The forts are discussed in their environmental situation, using information from historical sources and local knowledge, combined with recent aerial survey, to identify eroded features and hypothesize their former extent while indicating the rates of coastal retreat. The evidence is combined to suggest how promontory forts have changed since occupation, leading to greater understanding of their former involvement in the maritime cultural landscape of the Celtic Sea.

From a maritime perspective, the coastal promontory fort is easily seen from, and gives oversight of, the sea. They are fortifications on promontories and headlands that are identified by one or more banks and ditches cutting the peninsula off on their landward side. Previous work at promontory forts in Ireland include O'Kelly's excavations in Co. Cork at Portadoona to the east of Toe Head; Carrigillihy, just within the entrance to Glandore Harbour; and Dooneendermotmore, beside Toe Head [12]. Others include The Doon on the eastern side of Tory Island in Co. Donegal; Dalkey Island in south Co. Dublin; and Larrybane Head on the north mainland coast near Rathlin Island in Co. Antrim [13-15] (Figure 1).

The dating evidence from promontory forts is wide ranging. In Wales, on the Pembrokeshire coast, there is surrounding Late Bronze Age evidence, but most promontory forts are thought to have developed during the Iron Age [16] (p. 66). A promontory enclosure at Llansteffan Castle in Carmarthen produced a date of 6 th century BC for an early phase in the occupation sequence. Excavations at The Knave near Rhossili and the Bulwarks at Porthkerry, promontory forts in Glamorgan, produced pottery from the Iron Age and/or Roman period [17] (p. 26). Across the Bristol Channel, the Cornish promontory fort at The Rumps, close to the Camel Estuary, yielded Italian amphorae and was occupied from the 2nd century BC to the 1st century AD [17] (pp. 184-185) [18] (pp. 9-10]. In Scotland, similar later dates are found in Burghead and Green Castle on the Moray Firth occupied from the 3rd century AD until the 9th century AD and 7th to 8th centuries AD, respectively [19] (pp. 40-41). Excavations of a probable promontory fort on the North Solway Firth at Cruggleton Castle, a seat of the early Lords of 
Galloway, contained a roundhouse c. $8 \mathrm{~m}$ wide from which came a radiocarbon date of c. 1st century AD, a similarly dated bronze bow brooch, and a timber hall dated to the mid-8th century [19] (p. 40).

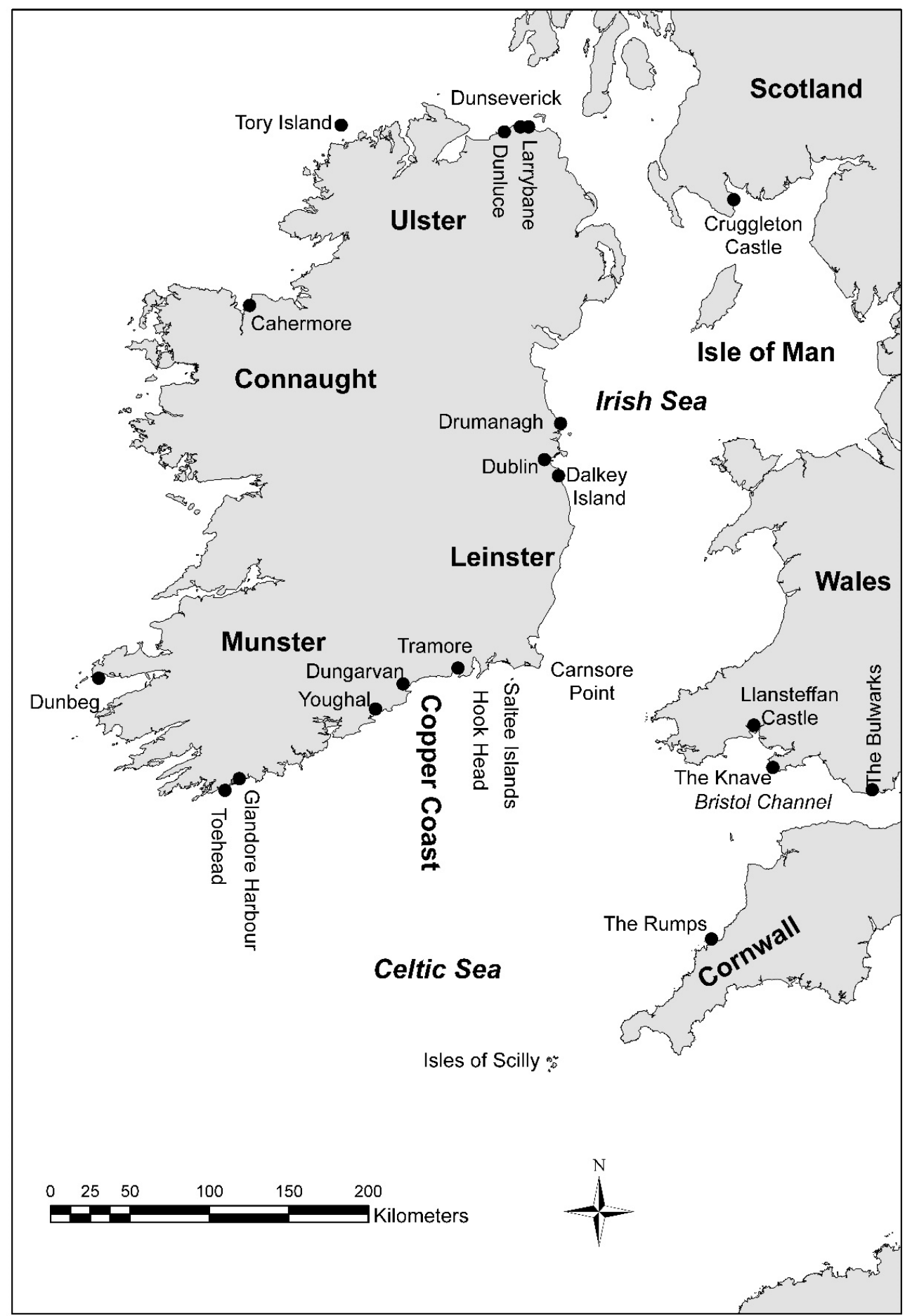

Figure 1. Ireland, with the location of Copper Coast and other sites mentioned in the text (the CHERISH project).

In Ireland, the promontory fort of Drumanagh in Co. Dublin is dated by metal-detected finds including late 1st- or early 2nd-century AD Roman coins [20] (p. 26). However, it is unclear whether the banks and ditches, features that define a promontory fort, date to that period. Gordon Childe dated Larrybane promontory fort from a glass bangle and combs to pre-9th century [14] (p. 104). Radiocarbon dating from the base of one of the fosses at Dunbeg indicated that the fort was being 
used in the 8th to 9th century, with the hut inhabited from the late 9th to 11th centuries AD, though the stone rampart was preceded by a shallow ditch that produced a carbon date of approximately the 6th century BC [21] (pp. 306-307, 312-316). On Dalkey Island, excavations revealed early medieval occupation prior to the construction of the promontory fort, within which were amphora, glass and bronze pins [13] (pp. 165-166). The presence of French E ware pottery in this assemblage sealed under the bank suggested the pre-bank deposit to be from post mid-6th century AD [22] (p. 95). The lower layers of the ditch of the promontory fort produced early medieval bone pins, and four bone cylinders common in Viking Dublin. This suggests that the fort was constructed after AD550 and the site was still in use during the Norse settlement though not necessarily for its original purpose.

Research into the coastal promontory fort is significant for several reasons. Primarily, from a physical perspective, they protrude into the sea, making them an unmistakable part of the maritime landscape and of vital importance to passing seafarers for navigation. Conversely, their occupiers can observe the sea lanes, allowing them to monitor and, to some extent, control traffic, and to take defensive action if necessary. This maritime function of features adds to previous interpretations, where promontory forts are considered alongside landward hillforts and defended farmsteads. It is also the case that their date of use is not properly understood, with many publications attributing them to the Bronze Age or Iron Age. Today, they are a monument found on both sides of the Irish Sea as well as Brittany. This could be interpreted as attesting to a former linkage of these areas and peoples, if contemporary, in a maritime culture. Finally, and of crucial importance from the practical standpoint of the ability to conduct archaeological research, these sites are especially sensitive in their environmental context. As a result of their exposed coastal location on clifftops, they are actively being eroded by the sea, with increased erosion likely from predicted climate change [23].

The Waterford Copper Coast has a striking complex, with at least 26 coastal promontory forts recorded today in the National Monument Record (NMR) within only $24 \mathrm{~km}$ between Tramore and Dungarvan, overlooking the Celtic Sea to the SW of Waterford City (Figures 1 and 2). However, none have been excavated, but all have been identified from local knowledge, site visits and aerial photographs to be under severe erosional threat. This paper begins with a broad discussion of the historical maritime situation along the Waterford coast. A more detailed examination of the concentration of promontory forts with the evidence for erosion is then presented with a possible model of how they used to look based on geology, geomorphology, historical evidence, and local tradition. This model suggests that several forts were linked and larger forts and concentrations of forts suggest control of sea routes and local resources. The rates of erosion deduced from examining missing sections in archaeological sites suggests how much cliff has been lost and how long surviving sites will last.

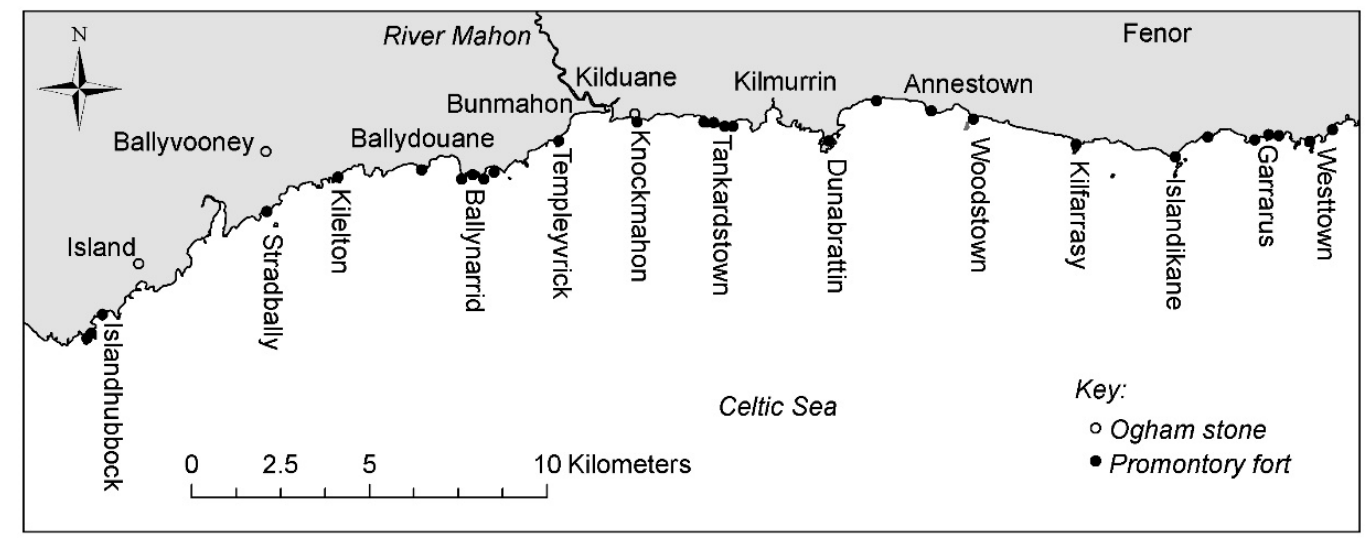

Figure 2. The promontory forts along the Copper Coast of Co. Waterford (the CHERISH project). 


\section{Materials and Methods}

The information presented has been gathered from desk-based research, field survey and aerial survey by manned light aircraft and unmanned aerial vehicles (UAVs) conducted between 2017 and 2019 in the context of determining the extent of erosion and the threat to coastal archaeology. The manned aerial surveys flew from Cork airport on 28th and 29th September 2017 to record the present state of the coastline for future reference and comparison to any earlier images that can be found. This was followed by another aerial survey undertaken on 25th October 2017 following 16th October Storm Ophelia (ex-hurricane Ophelia) to determine whether any damage had occurred to the forts. This latter survey happened to take place at a lower stage of tide. This identification of wider archaeological and geomorphological features from the manned aerial survey and archive research helped to determine the extent of the erosion at sites, the significance of the sites, and what sites should be prioritised for site-specific survey.

As this is a long-term study estimating change over a period of 1500-2000 years, and in the absence of high-accuracy map resources extending back over a century or more, no recourse was had to the GIS-based Digital Shoreline Analysis System (DSAS) [24]. Even 19th-century mapping covered in the OS 1st Edition of 1839-1841 lacks precision in the drawing of the coastline, so frustrating accurate measurement of coastal retreat over a reasonably extensive timescale. Furthermore, this investigation is a site-specific look at the effects of erosion and not a macro approach where the DSAS would be more valuable. However, present work incorporated in the CHERISH project will provide the baseline precision for comparative studies and future return recording at sites will enable the repeat surveys and the potential to identify specific areas of change. A recent wider-scale UAV survey by the Geological Survey of Ireland (GSI) will be scrutinised using a landscape approach to erosion.

All promontory forts along the coast lie in areas of privately owned farmland. Although there was a coastal path traversing large areas of the Copper Coast marked on earlier OS maps, it has been seriously eroded to the point of danger in many places. There are fishermen's paths with access to the shore from the road from Tramore to Dungarvan, but these are unmarked and only known locally. Access permission was always obtained from the local farmers concerned prior to field and UAV survey. The UAV surveys were conducted to determine the extent of archaeological features within the forts and in the surrounding fields. A DJI Phantom 4 Pro operated through the DJI Ground Station Pro app was used. The ground on inaccessible islands exhibits a covering of long grass that has not been grazed for c. 200 years and may obscure features: however, in some cases, banks, hut sites and enclosures could be determined from a change in vegetation. Further local knowledge of erosion and history was obtained during these visits. All field surveys were restricted to the tops of cliffs and thence landward due to the inaccessibility of many bays and coves that lie at the foot of the steeply eroding cliff-line.

The certainty that the landscape has changed to an extent dependent upon geology and resistance to erosion allows for some modelling of the late Iron Age and early medieval landscape to properly interpret its former appearance and likely exploitation. Evidence of erosion can be seen in a variety of features including scree, sea stacks and arches, tunnels, geos, and the wave-cut platform. The shallow extent of submerged rock in the wave-cut platform evidences continuations of the land, and can be seen indirectly through kelp beds that grow on hard substrate, and are visible as shadows on the breaker zone in the aerial photographs. The bedrock geology, once important for locating mineral resources for metal working groups that operated on this coast, was obtained from the GSI.

Additional evidence derives from local or oral tradition as to where sites were once located and where erosion is occurring. Information can also be found in place names, which record owners of sites, the resources found at a particular site, or where an event happened. One source, the Irish annals, were yearly listings of ecclesiastical and secular events recorded by the monastic communities [25] (p. 49), although it has been argued that this source is only reliable from AD650, postdating most references in the annals to promontory sites such as Illaunobrick in the study area. Earlier material comprises a pre-Christian "history" of Ireland and represents an attempt by later annalists to integrate 
Biblical and Classical history with Irish history by combining it with Irish oral traditions, myth and hereditary King Lists.

\section{Results}

\subsection{Environment}

The Waterford 'Copper Coast' lies between Fenor in the east and Stradbally in the west (Figure 2). Its name alludes to mining that occurred up to the 19th century and which is evidenced by adits in the cliffs, with shafts, spoil heaps, ore yards and engine houses landward, all located near promontory forts such as Tankardstown, Templeyvrick and Knockmahon. The rich mineral deposits were mined extensively from 1824 to 1908 in and around Bunmahon [26] (p. 336). The cliffs are composed of volcanic and sedimentary rocks from the Ordovician and Devonian periods [27]. The sedimentary rocks include mudstones, limestone and siltstones exposed at Dunabrattin Head and conglomerates in Ballydowane Bay and Bunmahon Head [28] (pp. 56, 60), [26] (p. 341). The volcanic features were formed from two submarine centres formed 450 million years ago. The western centre, called the Bunmahon Volcano, is composed of andesite, and was followed by the Kilfarrasy volcano, composed mainly of rhyolite. The sea cliffs, today, are up to $70 \mathrm{~m}$ high with occasional small sandy coves and bays. The spring tidal range of approximately $4 \mathrm{~m}$ affects the vertical incidence of marine erosion. Small rivers outflow into larger bays with sand bars such as the Mahon at Bunmahon and the Anne at Annestown. With reference to subaerial erosion, the Copper Coast experiences precipitation in the range of $800-1200 \mathrm{~mm} / \mathrm{yr}$, a significant, if low, amount, in an Irish context, while prevailing winds are south-westerly, impacting strongly on the east-west trending coast particularly in gale conditions [29].

\subsection{Historical Background}

A powerful group during the later Iron Age to the early medieval period in southern Co. Waterford were the Déisi [30] (pp. 147-150). Archaeological evidence of their claimed territory is found on inscribed ogham stones, which appear in Ireland in the 5th to 6th century. They are found on the Waterford coast at Ardmore, the townland of Island on the Copper Coast, and on the ancient road from Ardmore to Lismore to Cashel, where the kings of Munster were based [31]. The Knockmahon promontory fort, located to the east of Mahon Estuary at Bunmahon, contained two ogham stones, one of which read as SENAQ MAC (or Q) Q (or C), and it was postulated that Senaq is the same as Senach, who according to the Annals of Ulster had descendants who were kings of the Déisi in the 8th century [32] (p. 9). Evidence of religious persuasion lies in place names such as Kilfarrasy (Church of Fergus) promontory fort, Kilduane (Church of Duane) and Ballydowane (homestead of Duane). Duane or Dubhán was a 5th-century Welsh saint who set up a monastery on Hook Head, Co. Wexford. Moreover, the name Templeovrick, used both for a sea stack and the neighbouring townland (Templeyvrick), is indicative of a church (temple) associated with the name O'Bric. Some evidence that place names retain their pre-Christian names, and therefore perhaps Iron Age in origin, can be found in examples like Kilmurrin (church of Muirne), where Muirne was the mother of Fionn mac Cumhaill in Irish mythology.

According to the 17th-century historian Geoffrey Keating, the Déisi originally possessed the district of Déisi Dheisceirt from the River Suir southwards to the sea, and from Lismore to Creadan Head on western side of Waterford Estuary, up until the 5th century, when the king of Munster gave them Deise Thuaisceirt from the River Suir to the Plain of Cashel [33] (p. 187). The king of Déisi Thuaisceirt was O'Phelan, whose residence was on the River Suir to the west of Clonmel called Dun Ui Faoláin (Fort of O'Phelan). A kinsman of O'Phelan called O'Bric occupied Déisi Dheisceirt, and he had his stronghold beside the sea at Illaunobrick (Island of O'Bric) (Figure 3). The allegiance of the Déisi was divided between these two kings [34] (p. 194).

Along the Copper Coast, there are four promontory forts in the townland of Ballynarrid: two forts are at Rinnamoe on the western side, the main fort is probably Illaunobrick, also known as Danes 
Island, and Slippery Island is to the east of the townland. To the west of Ballynarrid in the townland of Ballydowane are a further two promontory forts: one on the western side of Cooneennacartan Cove, and the other immediately landward of Saint John's Island. To the east of Ballynarrid at Bunmahon Head in the townland of Templeyvrick is another promontory fort. The coast here displays many small islets and stacks including Saint John's Island, Templeobrick, Shag Island, Gull Island and Illaunwee. These seven promontory forts are bounded by the bays of Bunmahon to the east and Ballydowane to the west that are a mere $2 \mathrm{~km}$ apart.

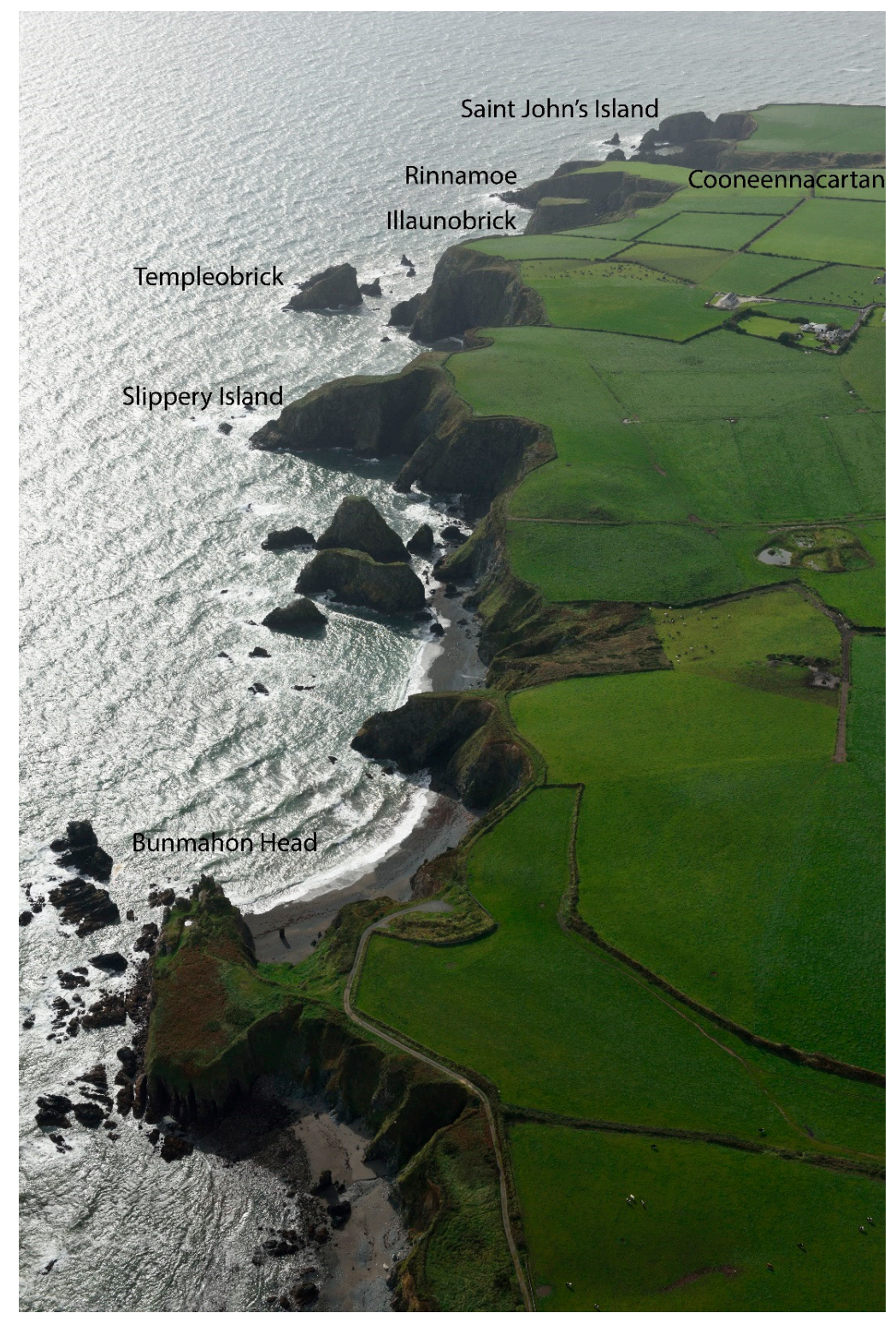

Figure 3. Aerial photograph looking west along the coast around Ballynarrid townland with Templeyvrick in the foreground and Ballydowane in the distance (CH_2017_0453 taken 28 September 2017).

A suggestion that the mines recorded around Illaunobrick are from the Bronze Age is refuted by the presence of a drill hole, which would point to the 19th century: (formerly fires would have been lit to crack the stone) [35] (p. 23). There is some evidence of external trade from the southern Waterford coast during the early medieval period, with medieval imported pottery from B ware (African Red Slipware tablewares and storage jars/amphorae) and E ware (coarse tablewares from the Loire Valley) at the Ballygarran ecclesiastical site (approximately $2 \mathrm{~km}$ upriver from Tramore Bay), and at Kilgrovan near Dungarvan [36] (p. 60). A copper ingot weighing approximately $0.5 \mathrm{~kg}$ (though only half remains) 
and cast in a circular mould was found c. $6 \mathrm{~km}$ upstream from the estuary at Bunmahon that is similar in shape to ingots made in Roman Britain [37] (pp. 88-89); and the National Museum of Ireland (NMI) topographic files record a wooden oak paddle and bailer found in old mine workings in 1850 approximately $21 \mathrm{~m}$ below the surface. As they were 'apparently of great age', this suggests that there was activity in the mines at least beyond living memories of the 19th century.

There are historical records beginning in Elizabethan times of mines being worked near Bunmahon. Francis Wyse, in 1748, took a 31-year lease from Lord Ormond for the mineral rights west of Bunmahon [38] (pp. 10-12). The NMI record an Irish 17th-century trade token found near Knockmahon Castle (the 'castle' may be referring to the promontory fort in this townland), which could have been associated with earlier mineral trading in this area. Wyse may also have been involved in a partnership working Lord Ranelagh's land, possibly near Annestown, in 1745 for copper. The geological memoir noted that this area was searched for copper but had limited success [39] (p. 56).

A geologist in 1824 observed that there were earlier mine workings at Illaunobrick: it was, however, possible to exploit the area for a further 40 years, yielding annually almost half a ton of pure silver along with approximately 75 tons of lead including veins up to $70 \mathrm{~m}$ extending below the seabed [38] (pp. 11-12). During the 19th century, the Mining Company of Ireland worked copper to the west and east of Bunmahon [39] (p. 82). During this 18th- to 19th-century period of industrial mining, the earlier exploited mines were called 'Danes mines' or 'old men's workings', indicating that they had little knowledge of when or who undertook the mining [40] (pp. 3-4). This period is probably when Illaunobrick became referred to as 'Danes Island', by migrants brought in for mining work, evidently aware that it was an ancient site but attributed its construction wrongly to the Vikings. Mines were excavated into the cliff, with vertical pits landward, and out to sea at Ballydowane, Illaunobrick and Templeyvrick for copper, lead and silver [38] (pp. 25, 27) [39] (p. 82).

\subsection{Fort Destruction by Erosion}

Table 1 shows the present characteristics of promontory forts along the Copper Coast. Intertidal erosional features such as stacks, stumps, arches, tunnels, caves and geos surround all sites and allude to a potential maximum extent when in use (Figures $3-5$ ). Some forts are very narrow ( $<10 \mathrm{~m}$ wide) in plan view, and impractical as settlements unless severely eroded since: such are Corcoran's Island in Annestown, and Faill na Smuite in the townland of Stradbally More. They both have surrounding islets: furthermore, directly seaward and extending $150 \mathrm{~m}$ in intertidal to shallow water are grass-covered islets, suggesting that they could also have been longer as well as wider (Figure 4). Faill na Smuite and Gull island lie on the boundary of igneous intrusions into shale and volcanic rocks of feldspar porphyry to the east and peperite to the west, the porphyry forming the harder material of the geomorphology. Similarly, Corcoran's Island is also related to a change in geology: this time a fault between (harder) rhyolitic and peperite volcanics. In both cases, the geological boundaries have resulted in harder rock forming linear features of limited width protruding into the sea. Today, they are too narrow for all practical purposes, but our measurement of the base of the cliffs and the offshore islands suggest that the original widths prior to erosion could well have been $60 \mathrm{~m}$.

Some promontory forts have larger islands directly seaward such as Woodstown and Islandikane. Both have hut sites indicating, unless in the unlikely event a bridge, they were once joined to the mainland. Islandikane sports Sheep Island and Rat Island rising seaward above the intertidal zone. In the early 20th century, Westropp recorded a tradition that a path once led to Sheep Island, and referenced earlier records of the splitting of Sheep Island and Rat Island to approximately 1841 [34] (pp. 221-222) [41] (p. 255). He described the piercing of the promontory by two natural arches, which fell into the sea around that time. Joined to the mainland, the islands would have made the fort $450 \mathrm{~m}$ long when in use though it is only $90 \mathrm{~m}$ from its bank to the cliff edge today. Presently, another arch lies directly below the hut site on Sheep Island, with further arches through the island forming after the 1st OS edition (1839-1841). 


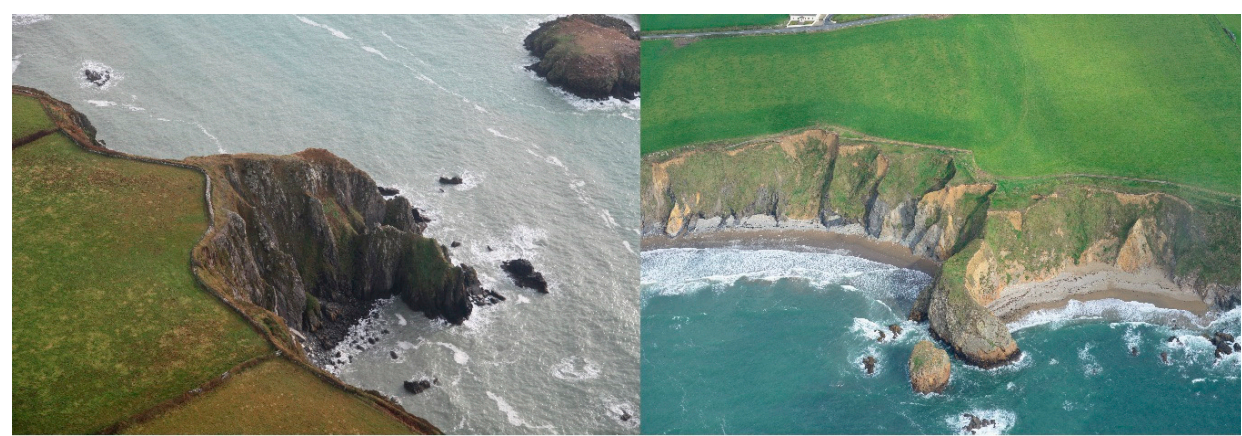

(a)

(b)

Figure 4. (a) The narrow promontory fort at the Faill na Smuite in Stradbally More sloping down towards Gull Island (3M6A0475 taken 25 October 2017); (b) Corcoran's Island promontory fort in Annestown (CH_2017_0381 taken 30 September 2017).

Table 1. Characteristics of promontory forts, listed from west to east, along the Copper Coast, combined from historic maps, Geological Survey of Ireland data, aerial survey, fieldwork, and references [34,41-43].

\begin{tabular}{|c|c|c|c|c|c|c|}
\hline Name & Townland & Geomorphology & Area (ha) & Height (m) & $\begin{array}{c}\text { No. of } \\
\text { Banks/Ditches }\end{array}$ & Geology \\
\hline Ballyvoyle Head 1 & Islandhubbock & Headland & 0.65 & 74 & 1 & Mudstone and sandstone \\
\hline Ballyvoyle Head 2 & Islandhubbock & Headland & 0.30 & 74 & 1 & Mudstone and sandstone \\
\hline Islanhobegg & Islandhubbock & Promontory & 0.27 & 50 & 3 & Mudstone and sandstone \\
\hline Faill na Smuite & Stradbally More & Promontory & 0.01 & 50 & 1 & $\begin{array}{c}\text { Shale and siltstone, peperite, } \\
\text { porphyry }\end{array}$ \\
\hline Ballyvoony & Ballyvoony & Promontory & 0.04 & 30 & 2 & Shale and siltstone, peperite \\
\hline Ballydowane West & Ballydowane West & Promontory & 0.12 & 40 & 1 & $\begin{array}{l}\text { Conglomerate, sandstone and } \\
\text { siltstone }\end{array}$ \\
\hline $\begin{array}{l}\text { Ballydowane East } 2 \\
\text { (Saint John's Island) }\end{array}$ & Ballydowane East & Promontory & 0.12 & 45 & 1 & $\begin{array}{l}\text { Conglomerate, sandstone and } \\
\text { siltstone. }\end{array}$ \\
\hline $\begin{array}{l}\text { Ballydowane East } 1 \\
\text { (Cooneennacartan } \mathrm{W})\end{array}$ & Ballydowane East & Promontory & 0.10 & 45 & 3 & $\begin{array}{l}\text { Conglomerate, sandstone and } \\
\text { siltstone, rhyolite }\end{array}$ \\
\hline $\begin{array}{c}\text { Rinnamoe W } \\
\text { (Cooneennacartan E) }\end{array}$ & Ballynarrid & Headland & 0.07 & 40 & 2 & Rhyolite, slate \\
\hline Rinnamoe E & Ballynarrid & Headland & 0.06 & 40 & 1 & Rhyolite, slate \\
\hline $\begin{array}{c}\text { Illaunobrick } \\
\text { (Danes Island) }\end{array}$ & Ballynarrid & Stack & 0.35 & 47 & 1 & Rhyolite, slate \\
\hline Templeobrick & Ballynarrid & Stack & 0.10 & c. 20 & 0 & Rhyolite, slate \\
\hline Slippery Island & Ballynarrid & Promontory & 0.16 & 45 & 2 & Basalt to andesite, shale \\
\hline $\begin{array}{c}\text { Joy's Island } \\
\text { (Bunmahon Head) }\end{array}$ & Templeyvrick & Headland & 0.72 & 20 & 1 & $\begin{array}{l}\text { Conglomerate, sandstone and } \\
\text { siltstone }\end{array}$ \\
\hline Knockmahon & Knockmahon & Promontory & 0.15 & 20 & 1 & Basalt, andesite shale \\
\hline Foilaneena Cashel & Tankardstown & Stack & 0.03 & c. 20 & 0 & Shale and siltstone, peperite \\
\hline Drumboe & Tankardstown & Promontory & 0.28 & 40 & 2 & Shale and siltstone, peperite \\
\hline Drumcappul & Tankardstown & Promontory & 0.16 & 40 & 2 & Shale and siltstone, peperite \\
\hline Foilboy Cashel & Tankardstown & Stack & 0.18 & c. 20 & 0 & Shale and siltstone, peperite \\
\hline Dunabrattin & Dunabrattin & Headland & 7.50 & 20 & 1 & $\begin{array}{l}\text { Calcareous clastics and } \\
\text { limestone bands }\end{array}$ \\
\hline $\begin{array}{c}\text { Dunabrattin } \\
\text { (subsidiary fort) }\end{array}$ & Dunabrattin & Promontory & 0.16 & 20 & 2 & $\begin{array}{l}\text { Calcareous clastics and } \\
\text { limestone bands }\end{array}$ \\
\hline An Rinn & Benvoy & Promontory & 0.30 & 20 & 1 & Shale and siltstone, peperite \\
\hline Corcoran's Island & Annestown & Promontory & 0.07 & 20 & 1 & Rhyolite, slate \\
\hline Woodstown & Woodstown & Promontory & 0.28 & 20 & 2 & Felsic volcanics \\
\hline Kilfarrasy Island & Kilfarrasy & Promontory & 1.08 & 45 & 1 & Felsic volcanics \\
\hline $\begin{array}{l}\text { Islandikane South } \\
\text { (Sheep's Island) }\end{array}$ & Islandikane South & Promontory & 1.35 & 30 & 1 & Felsic volcanics \\
\hline Islandikane East & Islandikane East & Promontory & 0.20 & 25 & 2 & Felsic volcanics \\
\hline $\begin{array}{c}\text { Garrarus } 1 \\
\text { (Illaunacoltia) }\end{array}$ & Garrarus & Promontory & 0.24 & 46 & 2 & Basalt and gabbro \\
\hline $\begin{array}{l}\text { Garrarus } 2 \\
\text { (Rinn Chaol) }\end{array}$ & Garrarus & Promontory & 0.07 & 15 & 3 & Felsic volcanics \\
\hline Garrarus 3 & Garrarus & Promontory & 0.02 & 15 & 1 & Felsic volcanics \\
\hline Great Island & Westtown & Promontory & 0.99 & 38 & 1 & Felsic volcanics \\
\hline Little Island & Westtown & Promontory & 0.10 & 23 & 1 & Felsic volcanics \\
\hline
\end{tabular}


Similarly, the bank and ditches of the Woodstown promontory are only $50 \mathrm{~m}$ from the cliff edge today but, if the fort is joined to its islands and islets (Green Island and Black Rock), it would make a promontory potentially up to $370 \mathrm{~m}$ in length (Figure 5). The hut site on Green Island that was identified from UAV data again suggests that this island was joined to the mainland. Green Island was split into two islands between the 1st (1839-1841) and 2nd (1897-1905) OS editions. Such landscape change would formerly have provided more shelter to the landing place at Annestown Beach to the west, and the probability that the beach itself may have been further seaward as well. In the early 20th century, Westropp argued that the extreme narrowness of the southern channel between Green Island and the Woodstown promontory fort was evidence that it has been cut through by the sea in recent times, and that a new arch formed through the centre of Green Island was an indication of further future island creation [41] (pp. 253-254). This east-west orientation of erosion seen in the island splitting and arch formation is also occurring along the ditch and bank area of the mainland part of the promontory fort where it has been indented and erosion is particularly noticeable today. It indicates a weakness in the bedrock in this direction, and forecasts that the future of the fort is to be dissected further into more island segments.

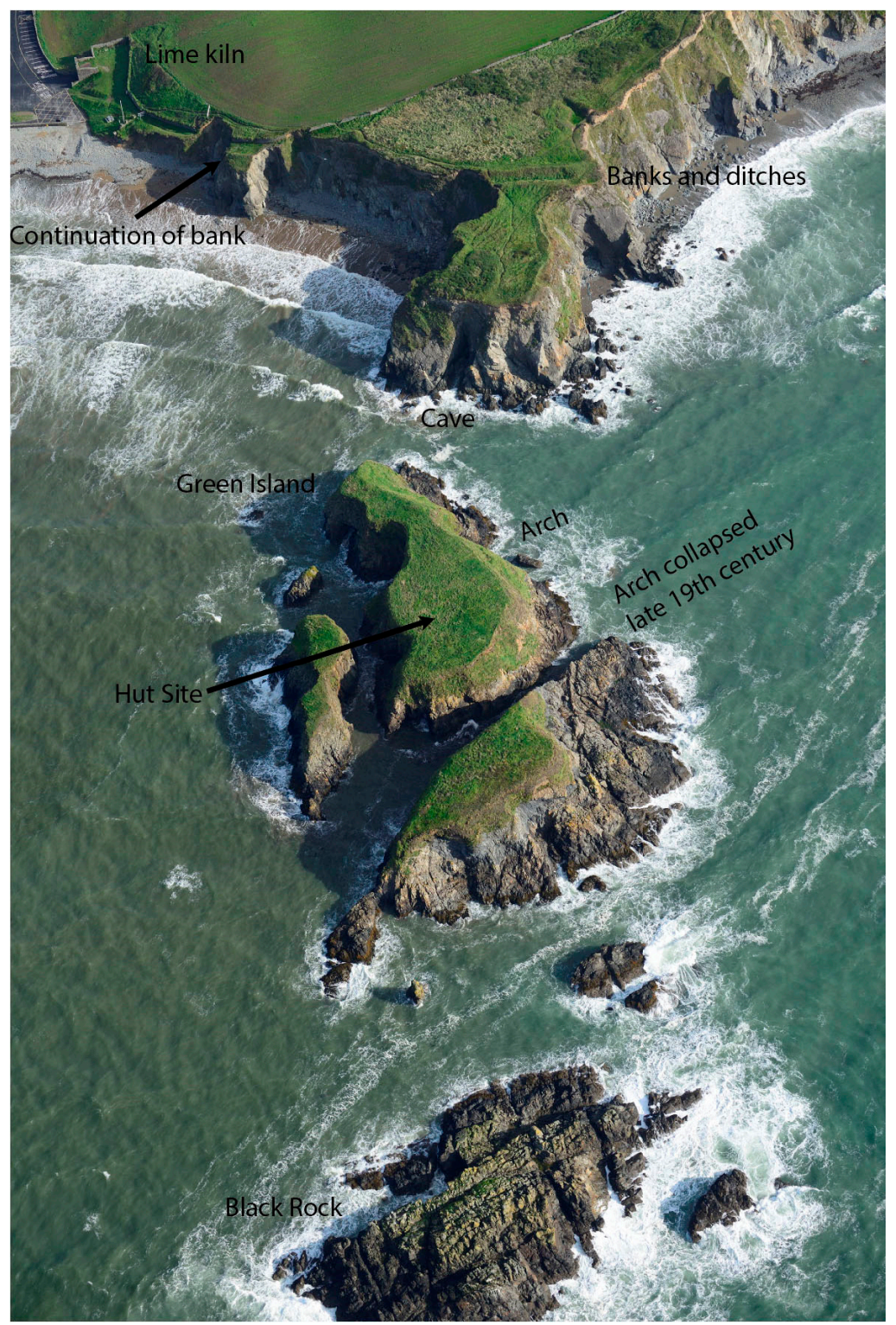

Figure 5. Aerial photograph of Woodstown promontory fort with features marked (CH_2017_0668 Table 29. September 2017). 
Westropp [41] (pp. 253-254), in remarking on the severe erosion at Woodstown, referred to the defences being eroded for $11 \mathrm{~m}$ west of the fort, save for slight mounds of an outer or landward ring (Figure 6). The path along the cliff from the lime kiln leading beside the beach to the west of the fort has been eroded away in sections. This path can be seen relatively clearly on the 1st-edition OS map though parts had started to erode by the 2nd edition. Along this path, approximately $80 \mathrm{~m}$ to the west of the present promontory fort's eroded banks is a small promontory with a trace of a bank visible in the aerial and UAV imagery that appears to be part of the continuation of the fort's embankments (Figure 5). This gives further indication of how much of the width of the fort has been lost, extending Westropp's $11 \mathrm{~m}$ to as much as $80 \mathrm{~m}$ lost. In an earlier guise, therefore, the fort would have continued much closer to Annestown Beach, and would enlarge its potential measurements to $120 \mathrm{~m}$ wide by $370 \mathrm{~m}$ long. This amounts to 4.44 ha, though it may conceivably have thinned seaward, thus halving the calculated area but, even so, a figure exceeding 2 ha is still much larger than the 0.28 ha today.

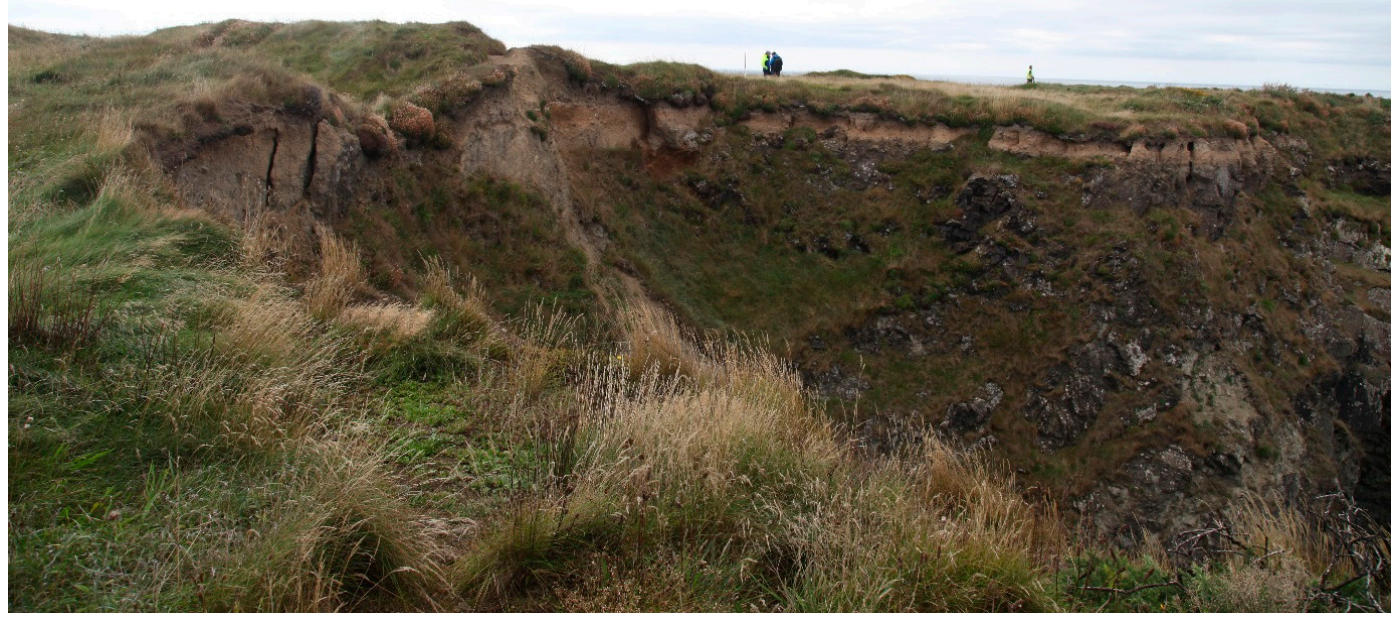

Figure 6. The banks and ditches eroding on the western side of the Woodstown promontory fort (CHERISH August 2018).

Around Tankardstown, an important 19th-century copper mining area, there is a group of sites situated within $600 \mathrm{~m}$ on two promontories and two stacks (Figure 7). The promontories Drumboe and Drumcappal have an enclosure landward that encloses both of them, suggesting that they were originally part of the same promontory fort, but which since has been eroded and divided. The stacks are less than $40 \mathrm{~m}$ from the present shore. They were originally considered sites by the National Monuments Service (NMS), as they were marked on the early OS maps as Foilboy Castle and Foilaneena Cashel, suggesting an oral tradition of a defended site. They were later removed from the site list, as NMS inspection saw no structures present today, perhaps due to erosion. However, the amount of erosion, closeness of the stacks to the cliffs, and mining in this area could have weakened the cliffs, leaving only an oral tradition of further promontory forts in this area. The cliffs are composed of volcanic peperite intruded into shale and siltstone, that forms the steep actively eroding cliffs seen on the aerial image. 


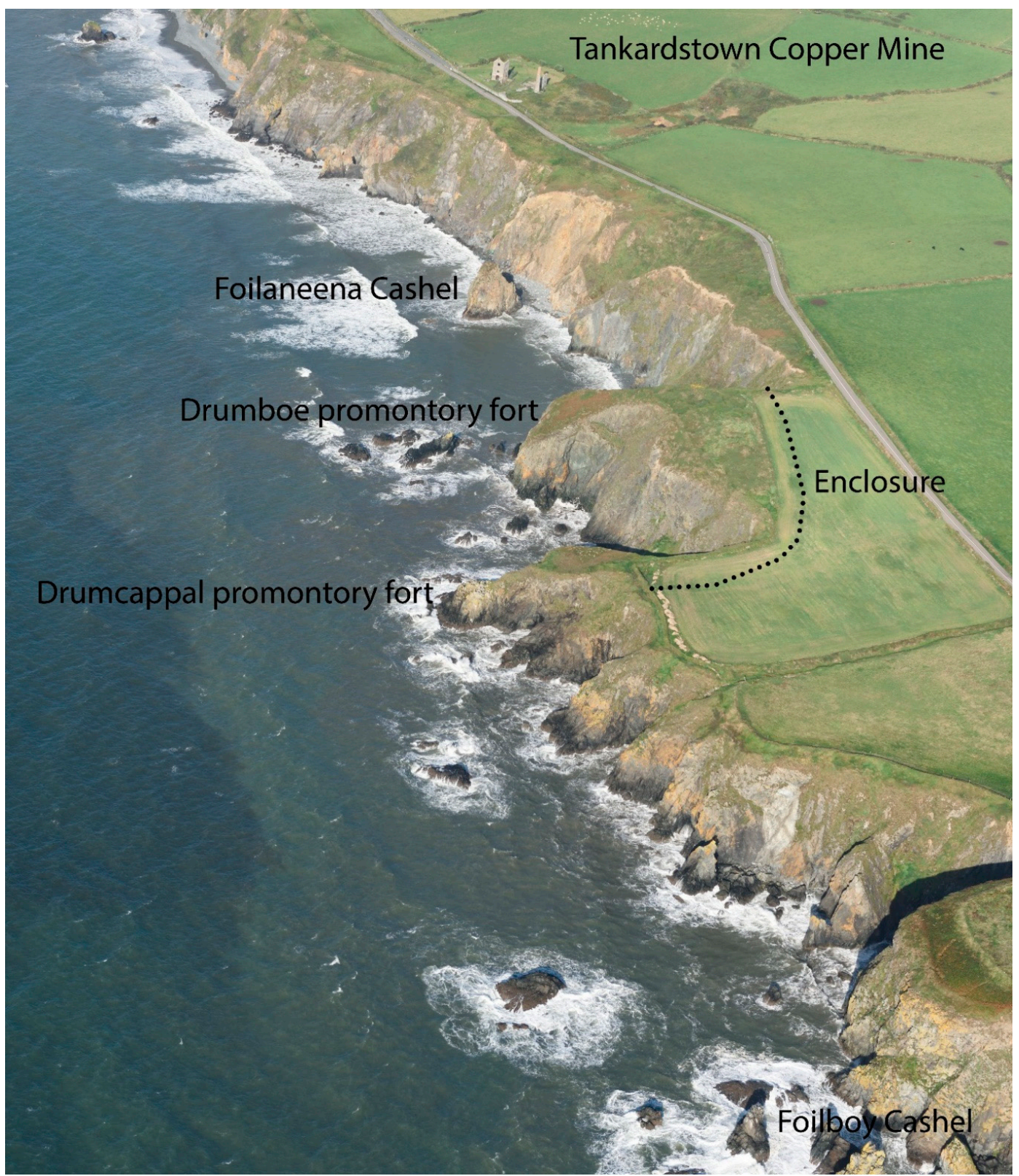

Figure 7. Sites around Tankardstown (CH_2017_0695 taken on 29 September 2017).

A fault exists between Foilaneena Cashel and Drumboe promontory fort, which lies $140 \mathrm{~m}$ west, orientated north-south. This may have been an area of weakness making it less likely that they were part of the same fort. Conversely, the evidence from Annestown indicated that faults can make stronger features in the landscape. Presently, Drumboe has an area of 0.28 ha (and Drumcappal is 0.16 ha) so, as such, they are relatively small forts. However, as it they are in an area of important copper resources, a larger fort may have been located here to control the area.

In the Ballynarrid area, erosion is severe with the promontory of Illaunobrick, a seat of the kings of the Déisi presently being described as a stack with only a 'goat track' access (Figure 8). This is in the area of copper, silver and lead mining into the cliffs, which has exacerbated the erosion. The surrounding area around Ballydowane and Bunmahon Bays has nine promontory forts located in a section of coast less than $4 \mathrm{~km}$, with seven concentrated in less than $2 \mathrm{~km}$. Some of these promontory forts are presently of limited area on narrow cliffs c. $50 \mathrm{~m}$ long and c. $10 \mathrm{~m}$ wide, such as two at Rinnamoe (Figure 3). 


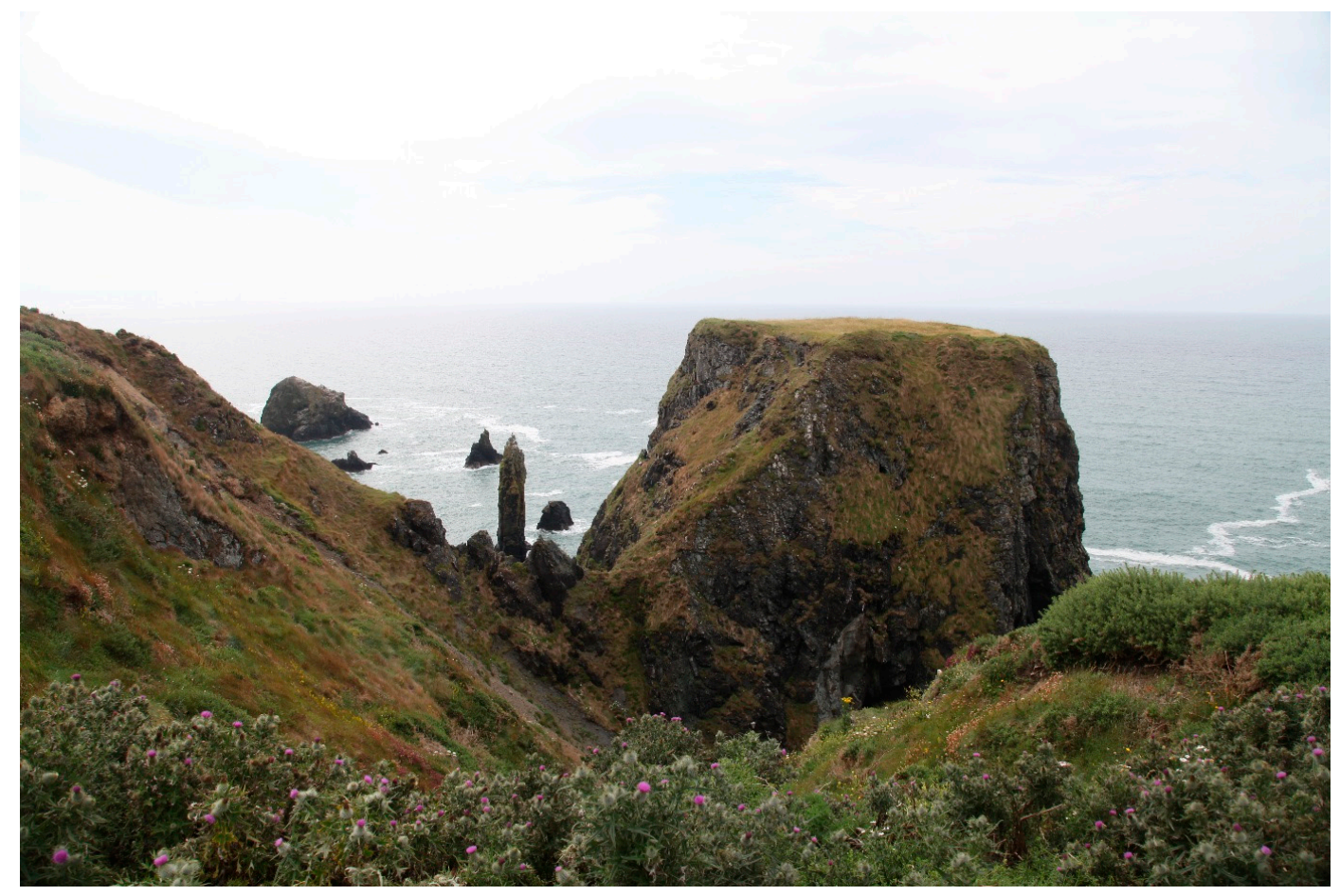

Figure 8. Illaunobrick promontory fort showing the eroded access to the site with Templeobrick amongst the stacks in the background (CHERISH 24 July 2019).

In Ballydowane townland, it is likely that Saint John's Island was once joined to the mainland, but is now separated by a chasm approximately $40 \mathrm{~m}$-wide (Figure 9). A low circular hut site $3.4 \mathrm{~m}$ in diameter close to the western edge of the promontory was found during aerial survey by Casey [43]. As there is a hut site on this stack, this suggests that there was direct access to this islet when the promontory fort was constructed. Vertical cliffs approximately $45 \mathrm{~m}$ high surround this area of coast and a sea tunnel running east-west through Saint John's Island called Poulatunish indicates further erosional features.

Approximately $100 \mathrm{~m}$ to the east of Saint John's Island, still in Ballydowane, is another narrow promontory fort (Figure 9). This is approximately $55 \mathrm{~m}$ long but only $18 \mathrm{~m}$ wide narrowing seaward. The fort has a series of three low earthen banks and two shallow intervening ditches across the neck of the promontory. Having three banks indicates an important fort, which seems a very large number of defences for such a narrow promontory. Therefore, this fort was almost certainly much larger than today. This is supported by stacks and rocky reefs to the south. Between this fort and Saint John's Island is a cliff of Old Red Sandstone call Foilrigeen. The farmer from Ballynarrid, said approximately 40 years ago the neighbouring farmer experienced a cliff fall at Foilrigeen when driving the tractor around the field. A missing section of clifftop field boundary could still be seen on the 2008 Google Earth image of this cliff, and where approximately $20 \mathrm{~m}$ of field boundary is gone and the indent is up to $10 \mathrm{~m}$.

The two promontory forts in Ballydowane site have their landward boundary at the interface between Old Red Sandstone shales and conglomerates clearly seen in the cliff behind and the volcanic andesite or rhyolite that forms the promontories. This was probably a fault line, an area of weakness that has been exploited by nature in the formation of the cliff, but also the builders of the promontory fort would have used this weakness to excavate their ditch. As there has been so much erosion between the two forts, it is very likely that these two forts are actually originally part of the same structure with the area between them subsequently eroded. This would explain why the eastern fort is so thin and narrow, with little space for a fort defended by three banks. The distance of $100 \mathrm{~m}$ between the forts is not unreasonable when the $40 \mathrm{~m}$ to Saint John's Island has also been eroded. Some of the eroded 
material between these forts may be discerned by the bedrock on aerial images on the foreshore, as this marks where the eroded cliff could originally have reached.

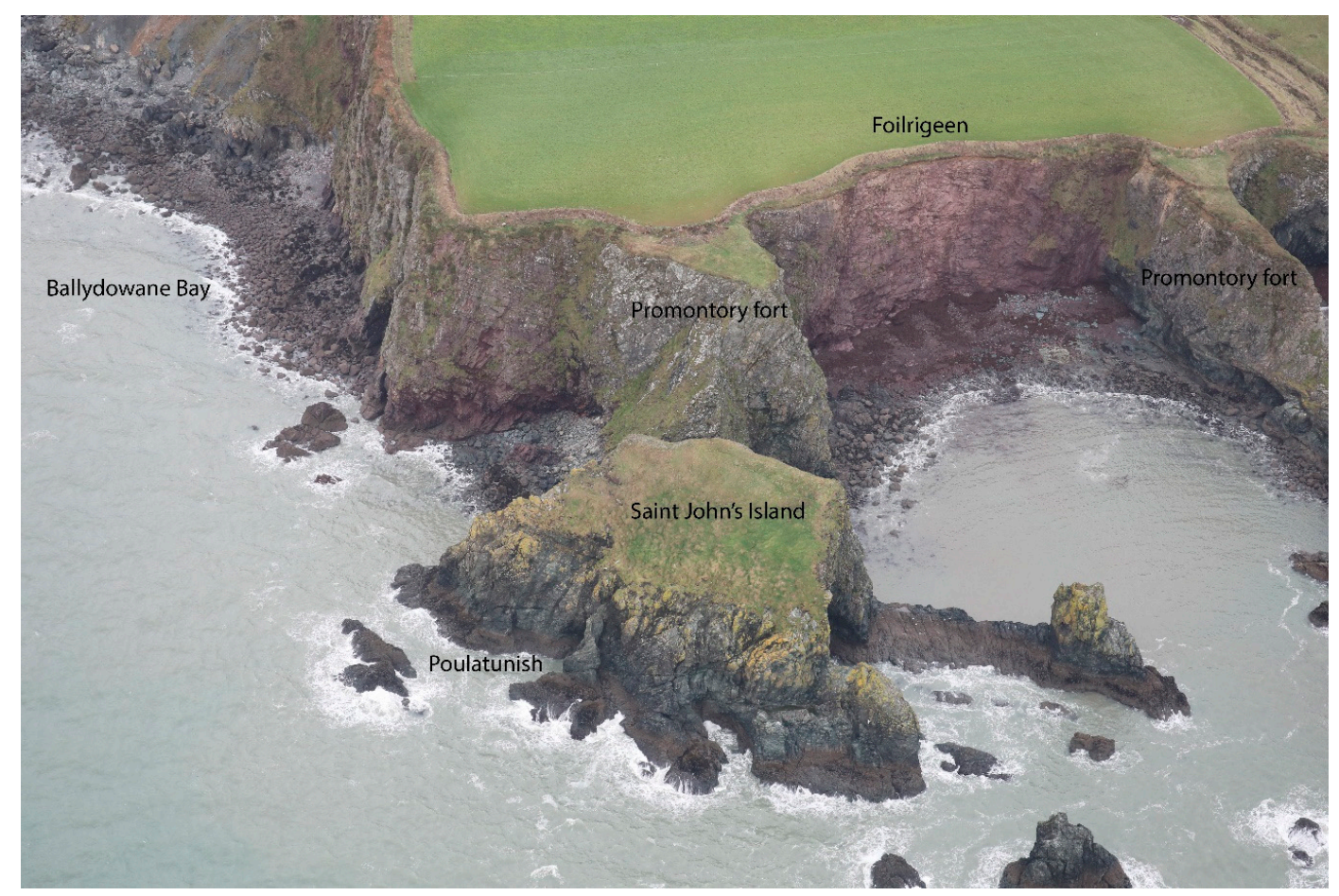

Figure 9. Saint John's Island showing the sea tunnel of Poulatunish underneath Saint John's Island, with two promontory forts landward separated by the Old Red Sandstone cliffs (CHERISH 3M6A0441 taken on 25 October 2017).

In a similar manner, the two narrow forts at Rinnamoe in Ballynarrid could have been connected. The distance between them is just $80 \mathrm{~m}$, stacks are present between them, and the ditch and banks could have linked up in the past. They are each up to $10 \mathrm{~m}$ wide and $80 \mathrm{~m}$ long, protruding into the sea, and a NMS visit in 1989 remarked that it is an unsuitable place for a promontory fort (not envisioning what they could have looked like prior to erosion). It is unlikely that they were connected to the promontory forts to the west in Ballydowane because the stream flowing into Cooneennacartan would always have divided this area and lowered the cliff line. That there were two banks and ditches indicates a promontory fort of some significance greater than for fishing access to the shore as it is used today. The field north of the Rinnamoe promontory forts is known as 'Castle Field' though there is no evidence for a castle on the early maps, suggesting that the feature must be older and that the promontories had more significance in the past.

Today, Illaunobrick stands dramatically when viewed from the mainland, with almost vertical cliffs $47 \mathrm{~m}$ high and a table-top summit 70 by $50 \mathrm{~m}$ in area only connected today by an impassable steep-sided isthmus $65 \mathrm{~m}$ wide. The adit mining in the cliffs around Illaunobrick, the next promontory fort to the east, has contributed to erosion by weakening the structure of the cliffs (Figures 8 and 10). This has been followed by large-scale collapse, perhaps making a significant difference in the shape of the coastline since the promontory was occupied. Two adits have previously been identified by local historian Des Cowman on the NW side of Illaunobrick that continued on the mainland at the SE side of the small promontory at Foilnalaun [35] (p. 25). These were identified as Wyse's adits in a report by a mining consultant Henry Price in 1824 to the Hibernian Mining Company that described a copper vein c. $14 \mathrm{~m}$ to the east of Illaunobrick. Cowman determined the land between these adits had eroded away if they were exploited as the single copper vein described in the report.

Further erosion is described with a rock fall in the winter of 1980-1981, revealing another copper vein on the east side of the isthmus within $14 \mathrm{~m}$ of an opening on the west side of Illaunobrick [35] 
(pp. 22, 25). On the NE side of Illaunobrick, two adits were buried by a rock fall c. 1973. This reveals the level of erosion since the 18th and 19th centuries, which has been exacerbated by mining for which purpose 13 adits are known in the cliffs (Figure 10). Today, the cliff collapse can be seen from scree around the isthmus, while a cove on the SE side of the stack indicates that not all erosion has been caused by mining.

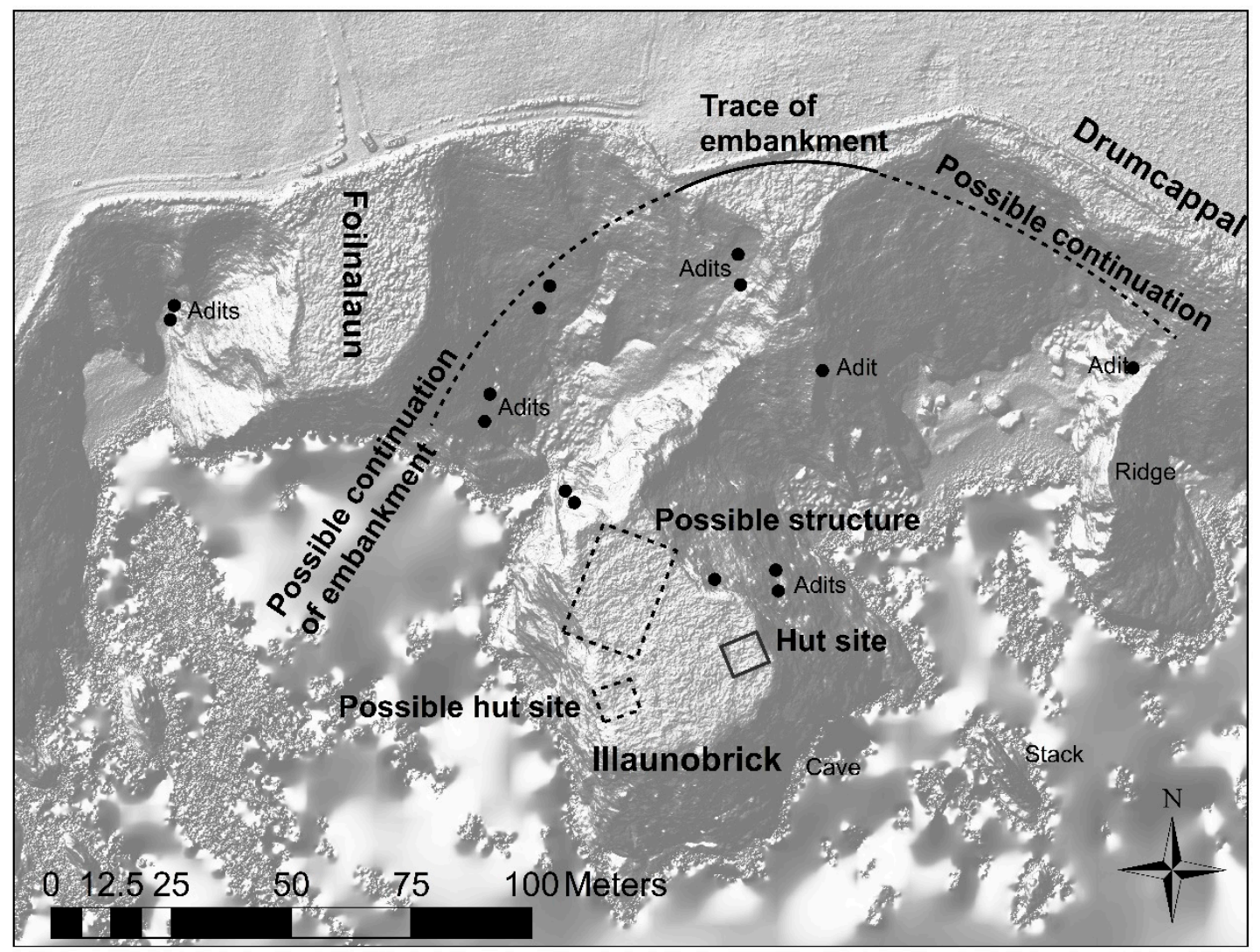

Figure 10. Digital Terrain Model of Illaunobrick from unmanned aerial vehicle data showing mines and promontory fort features (the CHERISH project).

The 1st OS edition (1839-1841) marks a 'site of entrenchment' on the landward side of Illaunobrick, suggesting that there was local knowledge of banks and ditches here which had eroded by 1840 . Today, a trace of a bank exists for $60 \mathrm{~m}$ in the overgrown ungrazed land on the seaward side of the farm wall opposite the stack. This disappears on both termini into steep cliff coves with scree probably from mining and cliff collapse. It is likely that the promontory fort builders used the weakness in the rock to build their ditch and pile up the bank beside it. The erosion along the line of the defences parallels events at Woodstown. The ditches and banks appear more susceptible and have consequently endured more erosion than other parts of the promontory to form the stack today. Mineral veins in joints in the rock were exploited by miners, further encouraging erosion. Thus, it might be surmised that the entrenchment crossed the presently eroded area between Foilnalaun and Illaunobrick, which has now collapsed apart from the narrow isthmus seen today.

There is possible further evidence of a once more substantial mainland connection in the translation of the Irish name Foilnalaun as 'cliff of the island'. The term 'island' is common along the Copper Coast, frequently on other promontory forts which are not actual islands, for example being found in the place names Islandhubbock, Joy's Island, Slippery island and even in the townland called Island, where the most noticeable feature is a landward circular ecclesiastical enclosure. The term 'island' may thus be a reference to a more subconscious separation of forts and enclosures by building ditches and banks to mark an area different from the 'land'. 
There is a folk memory that the O'Bric stronghold was not on Illaunobrick but on a large isolated rock called the Templeobrick, approximately $37 \mathrm{~m}$ from the shore and adjacent to the Illaunobrick [44] (p. 5) (Figures 3 and 8). More than a century ago, Westropp [41] (p. 252) pointed out a group of islets in shallow water to the east of Illaunobrick. They included 'a huge menhir of rock, a natural edifice called Templeobrick'. It was even earlier recorded in the OS letter 55 of 1841 [45], which stated that the foundations of an ancient building were still distinctly visible there in 1841. Today, Templeobrick is a stack only $50 \mathrm{~m}$ long and $15 \mathrm{~m}$ wide at most. It is approximately $75 \mathrm{~m}$ from the shore at high tide and maybe only $15 \mathrm{~m}$ at low tide.

As there appears to have been erosion of up to at least $80 \mathrm{~m}$ in the area, it is not impossible to conjecture that the sea stack, now marked as the island of Templeobrick, was once connected to the mainland. This would have been a particularly exposed promontory, and that, together with the mining activity, would have combined to severely weaken the cliffs perhaps from as far back as the Iron Age. Templeobrick does have a group of other islets surrounding it that, if connected, would have formed a promontory fort approximately $100 \mathrm{~m}$ wide and $150 \mathrm{~m}$ long assuming the banks and ditches lay in the area of the eroded intertidal zone.

Only $300 \mathrm{~m}$ to the east is another much eroded promontory fort of Slippery Island (Figure 3). Slippery Island's constricted isthmus is defended by two earthen banks, but today is only up to $7 \mathrm{~m}$ wide. This narrow fort is defended by two earthen banks with a causeway for access and is $80 \mathrm{~m}$ long but, as with Templeobrick, could have been almost twice that length in its heyday.

\section{Discussion}

Figure 11 shows the modern cliff line with potential areas that have eroded over the last 1500 years linked together from the surrounding stacks and stumps paying attention to geos and inlets. It looks at where the man-made features have been recorded to see their possible furthest extents. Extensions have been placed on the banks and ditches where they can be seen eroding off the cliff. Some of the promontory forts have been connected using this method such as the Ballydowane and Rinnamoe promontories making a larger fort where no erosional stream valley lies between them. By extending a promontory to include Templeobrick there is a narrow section where the banks and ditches may once have existed that follows geos on the rock platform exposed on the foreshore. A further possible extension of the cliff is also marked based on the shallow water rocky substrate that shows up clearly in aerial data as dark patches reflecting the rock or kelp that grows on the hard surface. This indicates the maximum seaward extension of the cliffs prior to sea level rising after the Ice Age, although that would encompass a long period before the building of the promontory fort. The purpose of the latter full extension is to show that the areas marked, including the stacks and stumps, are relatively conservative in the estimation of the coastal cliff extent at the time of probable promontory fort use.

When the landscape is reconstructed, we can see the potential for five, much larger than today, forts of approximately 2-4 ha. Only Dunabrattin, along the Copper Coast, is a larger promontory fort than this today (Table 1). Dunabrattin may be contrasted by its foundation on a different bedrock of clastics and limestone. As that bedrock material has suffered less erosion, it could provide a more realistic indication for the former size of forts. It has been calculated above that Woodstown promontory fort may have had an area of 2 ha. It lies beside Annestown Beach, which would have been a safer sandy landing place for larger sea-going vessels than the smaller rocky coves to the east. This sandy landing place is similar to Ballydowane Bay to the west of the Saint John's Island promontory fort. The forts probably had a function controlling traffic entering the landing place.

The importance of Illaunobrick is shown in the place name that refers to an important Déisi family that appears in early medieval Irish literature. This is based on earlier oral histories of the kings of Munster which mention Illaunobrick as part of a division of the king's territory between his sons [34] (p. 220). Furthermore, the kings recorded their founder Éogan Mór fleeing high king of Ireland Conn of the Hundred Battles down the River Suir and across Co. Waterford to Illaunobrick. 
These stories would have had a purpose in a land where oral tradition was used to display the ancestry and territories of kings, and it shows their presence in that location for a significant period of time.

The oral tradition indicates Illaunobrick's location as a defensible site. The need for a defended site is also evident from the later historical records of battles in the region. For example, in the 9th century Vikings were raiding Déisi land, while the Déisi themselves destroyed a Viking fleet and fort in east Co. Cork at Youghal. The Déisi also battled neighbouring Irish territories but, by the 10th century, were working with the Vikings of Waterford to defeat an army of Cashel. The O'Bric family are referenced in the Annals of Ulster in the 11th century when Finnguine Ua Finnguine, royal heir of Munster, was slain by Maelsechlainn O’Bric, king of the Déisi [34] (pp. 193, 220).

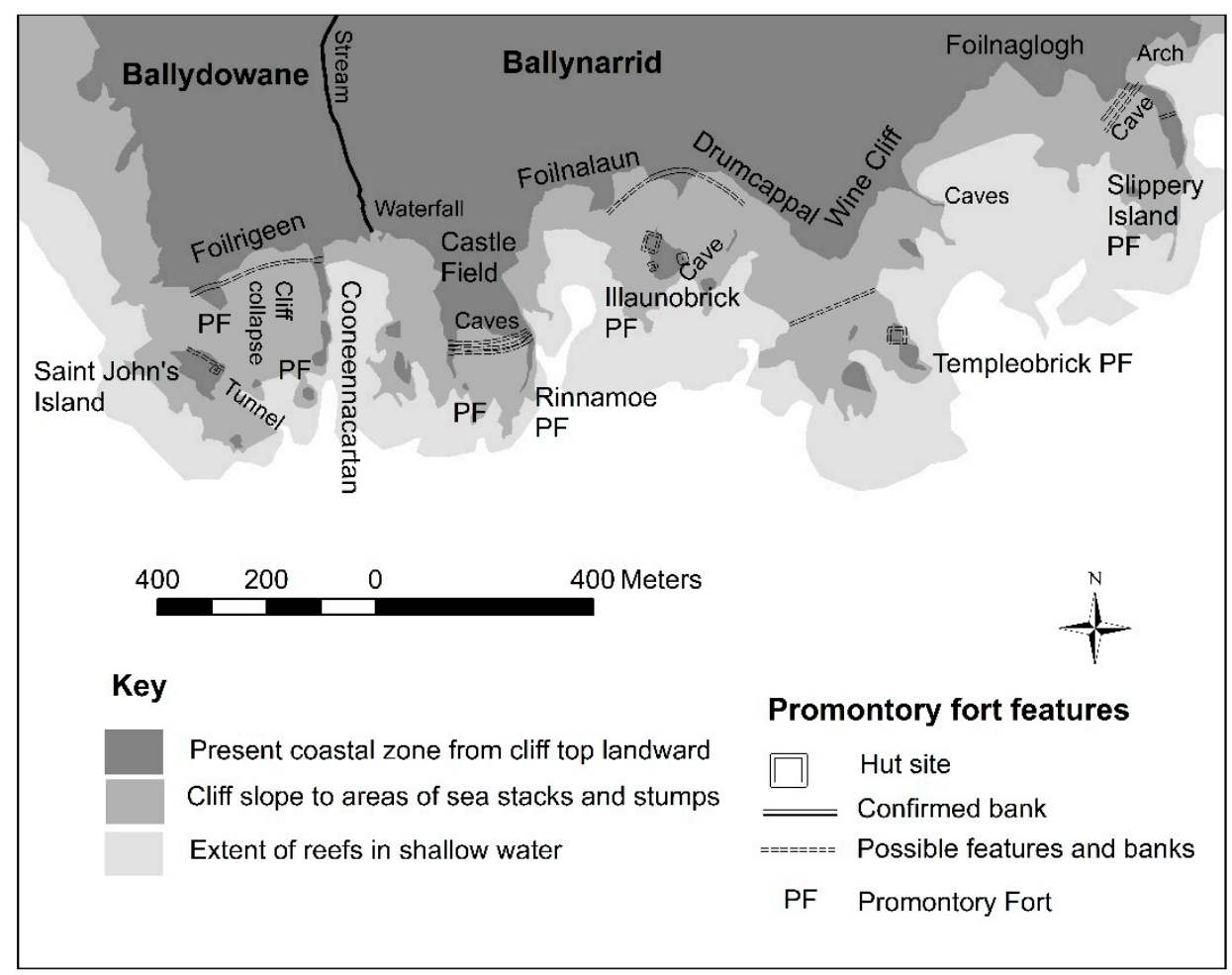

Figure 11. Modern cliff line and possible extent of eroded ground and archaeological features around Ballynarrid.

Seven promontory forts are recognisable today in the stretch of $2 \mathrm{~km}$ of coastline around Illaunobrick, pointing to a relatively dense population for the late Iron Age and the early medieval period when Irish settlement was generally dispersed. The suggested original extent of the five larger promontory forts also supports the existence of an important location. In that sense, Illaunobrick could be described as a 'central place' with many more functions than primary farming and fishing activities. The historical record of mining around Illaunobrick shows that this was an important resource area that would have increased trade opportunities and links benefitting from its coastal location. In the 8th-century a copper mine is recorded in Irish law as enhancing the value of land [40] (p. 3). In the Expulsion of the Déisi, an 8th-century manuscript describing their earlier origins, and settlement in Wales, there is a reference translated as 'people of the rivets' referring to their involvement in metal (potentially copper) rivet manufacture [38] (p. 24).

Having more than one bank and ditch suggests further importance of individual promontory forts, which can vary up to three banks where there is evidence left today. Only three sites along the Copper Coast have three banks or ditches including Cooneennacartan West in Ballydowane beside Ballynarrid townland (Table 1). Multiple banks are more effort to construct and can be seen as extra impressive from the land but also from the sea when passing or landing vessels observe the fort. The eroded Templeobrick can still be clearly seen today from the promontory forts at Ballyvoyle Head $7.7 \mathrm{~km}$ to 
the west. The stone structure reported on the Templeobrick stack in the 19th century must have given the name to the neighbouring townland of Templeyvrick, the area of which included the townland of Ballynarrid on the Down Survey of 1657 [46]. This indicates that the stack was an important feature or place, which is further supported by the oral tradition. The 1665 Dutch Atlas Maior published by John Blaeu marks only a few places on this coast including Dungarvan haven, Ile Inerick (Illaunobrick), and Stranmore bay (Tramore). Showing Illaunobrick indicates its importance and view from passing navigating traffic. Templeobrick is more prominent, protruding seaward, and would have been even more impressive in the past prior to significant erosion episodes. Illaunobrick, although nearer the shoreline than Templeobrick and situated in a bay, reaches a higher elevation and may have been seen from a further distance when navigating towards this area of the coast.

The DTM model of Illaunobrick has also revealed hut sites on the island (Figure 10). These include square features, approximately $10 \mathrm{~m}^{2}$, in the SE and SW of the stack. Another larger rectangular feature is eroding off the northern part of the island. They are not in the same position as the three hut sites indicated on the 1st-edition OS map. However, as access to the island during the OS survey was only open to wildfowlers, it is likely the hut locations are not accurate, but rather came from local knowledge and were merely sketched in.

The amount of erosion along the Copper Coast has differed for the rock type and presence of structural features such as joints and faults. The volcanic rhyolite and andesite areas have endured a conservative estimate of approximately $80 \mathrm{~m}$ of erosion evidenced from the gaps in defensive banks and ditches, and islets that remain today but are no longer connected to the mainland. If we date the promontory forts to approximately the 6th century AD like Dunbeg and Dalkey, this suggests erosion rates of $5 \mathrm{~m}$ per century, or an average of approximately $5 \mathrm{~cm} / \mathrm{yr}$. If the promontory forts are older as oral tradition suggests similar to the promontory fort of Drumanagh in Co. Dublin, and other Iron Age forts in Britain to be c. 2000 years old then the rate of erosion is c. $4 \mathrm{~cm} / \mathrm{yr}$. These are conservative estimates and do not take into account the mining, which also weakened the cliffs around Illaunobrick. Satellite data analysis of coastal coal mining north of Istanbul, Turkey, from the 1980s shows an initial accretion from extraction waste disposed into the sea, with coastal erosion becoming more dominant after 1992 as coal was replaced by natural gas [47]. Furthermore, it needs to be remembered that cliff collapse on a promontory could occur in three directions, considerably multiplying the erosion rate, while, on the island remnants, the attack is from all directions, if differentially dependent on predominant wave incidence.

The collapse often occurs in large sections rather than gradual wearing of the cliff as happened at Ballydowane c. 40 years ago, and after rain and storms at Dunbeg during the last two centuries. The rates of change are not significantly different to that of the chalk cliffs of east Sussex [11]. Similarly, on the promontory of Dunluce Castle, erosion rates calculated from local tradition of kitchen collapse into the sea in the 17th century, and missing sections of the 13th- to 14th-century barbican tower, indicate that approximately $6 \mathrm{~m}$ had eroded by the time a 19th-century plan was drawn [48] (p. 393). That is c. $1 \mathrm{~cm} / \mathrm{yr}$ erosion rate for basalt cliffs over $30 \mathrm{~m}$ high.

\section{Conclusions}

The oral tradition, historical evidence, ogham stones, imported pottery, and the concentration of promontory forts suggest that this area of $\mathrm{Co}$. Waterford was a powerful maritime community since the Iron Age controlling natural resources and had links across the Irish and Celtic Seas. Reconstructing the coastline suggests that forts were not only wider, longer and higher connected to nearby islets and stacks but some of the smaller forts, now considered to be separate monuments, were part of the same fort. The analysis suggests that in a maximum period of 350 years, there will be no traces left of any promontory forts around Illaunobrick, and other volcanic promontories on this stretch of coast. This time could be much reduced given expectations of worsening erosion with climate change, associated sea level rise and wave attack. It is not inconceivable that some promontory forts have already succumbed to the ravages of the combined attacks of aerial and marine erosion. This study 
highlights the vulnerability of what little remains, not least on this exposed southern coast of Ireland. This paper comes about after initial project surveys of the eroding heritage and further monitoring is scheduled over the six-year project. The scenario presented underlines the urgency of pressure upon archaeologists to investigate the remnants of structures whose size and location is a clear reflection of the former key role that they played in the coastal political economy of a period of exceptionally sparse written documentation. While limited remains, exposure and safety issues render their management or conservation difficult, if not impossible, in most cases, it is vital to record for posterity, and attempt to interpret, those vestiges that remain.

Author Contributions: Conceptualisation, E.P., A.C., S.H. and R.S.; methodology, E.P., S.H. and R.S.; software, A.C. and R.S.; validation, A.C. and R.S.; formal analysis, E.P.; investigation, E.P., A.C., S.H. and R.S.; resources, E.P., S.H. and R.S.; data curation, R.S.; writing — original draft preparation, E.P.; writing-review and editing, E.P. and S.H.; visualisation, E.P. and R.S.; supervision, A.C.; project administration, A.C.; funding acquisition, A.C. All authors have read and agreed to the published version of the manuscript.

Funding: The Climate, Heritage and Environments of Reefs, Islands and Headlands (CHERISH) initiative is a six-year EU-funded project that began in 2017. This work was supported by the EU Funds: Ireland Wales Programme 2014-2020 under WEFO Ref. No. 80886.

Acknowledgments: This paper comes from aspects of research being undertaken by the CHERISH project into erosion of coastal heritage in Wales and Ireland of which the promontory fort has been identified as a vulnerable and understudied feature around the Irish Sea. The authors would like to thank land owners John McKeown from Ballynarrid, Ted Cronin from Woodstown, Tom O'Sullivan from Islandhubbock, and Ivor Murphy from Dunabrattin. Toby Driver and Daniel Hunt from The Royal Commission on the Ancient and Historical Monuments of Wales undertook the first aerial survey in 2017. Kieran Craven and James Barry from the GSI provided geological GIS data. Thanks to Linda Shine from the Discovery Programme for guidance on medieval Irish sources. Simon Dowling reported areas of potential from his UAV survey and advice on the area. We would also like to thank the four anonymous reviewers for their helpful suggestions and encouragement on the manuscript, Gary Robinson for allowing us the opportunity to contribute to this special edition, and Assistant Editor Nicholas Ren for manuscript processing.

Conflicts of Interest: The authors declare no conflict of interest.

\section{References}

1. Markham, A. The growing vulnerability of World Heritage to rapid climate change and the challenge of managing for an uncertain future. In Public Archaeology and Climate Change; Dawson, T., Nimura, C., Lopez-Romero, E., Daire, M.-Y., Eds.; Oxbow Books: Oxford, UK, 2017; pp. 10-22.

2. Wang, S.; McGrath, R.; Hanafin, J.; Lynch, P.; Semmler, T.; Nolan, P. The impact of climate change on storm surges over Irish waters. Ocean. Model. 2008, 25, 83-94. [CrossRef]

3. EEA. Global and European Sea Level. 2017. Available online: https://www.eea.europa.eu/data-and-maps/ indicators/sea-level-rise-5/assessment (accessed on 16 January 2018).

4. Momber, G.; Tidbury, L.; Satchell, J.; Mason, B. Improving management responses to coastal change: Utilising sources from archaeology, maps, charts, photographs and art. In Public Archaeology and Climate Change; Dawson, T., Nimura, C., Lopez-Romero, E., Daire, M.-Y., Eds.; Oxbow Books: Oxford, UK, 2017; pp. 34-43.

5. Momber, G.; Scaife, R.; Gillespie, J.; Nayling, N.; Hamilton, D.; Marshall, P.; Bronk Ramsay, C.; Cook, G. Rising waters, environmental change and humans at BC-IV. In Mesolithic Occupation at Bouldnor Cliff and the Submerged Prehistoric Landscapes of the Solent; Momber, G., Tomalin, D., Scaife, R., Satchell, J., Gillespie, J., Eds.; Council for British Archaeology: New York, NY, USA, 2011; pp. 94-104.

6. Daire, M.-Y.; Lopez-Romero, E.; Proust, J.-N.; Regnauld, H.; Pian, S.; Shi, B. Assessment of the Vulnerability of the Coastal Heritage in Western France. J. Isl. Coast. Archaeol. 2012, 7, 168-182. [CrossRef]

7. Westley, K.; McNeary, R. Assessing the Impact of Coastal Erosion on Archaeological Sites: A Case Study from Northern Ireland. Conserv. Manag. Archaeol. Sites 2015, 16, 185-211. [CrossRef]

8. Bates, M.; Nayling, N.; Bates, R.; Dawson, S.; Hews, D.; Wickham-Jones, C. A Multi-disciplinary Approach to the Archaeological Investigation of a Bedrock-Dominated Shallow-Marine Landscape: An example from the Bay of Firth, Orkney, UK. Int. J. Naut. Archaeol. 2013, 42, 24-43. [CrossRef]

9. Arch-Manche. Coastal Management: A Guide to Using Archaeological, Palaeoenvironmental, Historical and Artistic Resources; Maritime Archaeology Trust: Southampton, UK, 2014. 
10. Bonsall, J.; Moore, S. The MSAC Project (Monitoring the Archaeology of Sligo's Coastline): Engaging local stakeholder groups to monitor vulnerable coastal archaeology in Ireland. In Public Archaeology and Climate Change; Dawson, T., Nimura, C., Lopez-Romero, E., Daire, M.-Y., Eds.; Oxbow Books: Oxford, UK, 2017; pp. 62-71.

11. Hurst, M.; Rood, D.; Ellis, M.; Anderson, R.; Dornbusch, U. Recent acceleration in coastal cliff retreat rates on the south coast of Great Britain. Proc. Nat. Acad. Sci. USA 2016, 113, 13336-13341. [CrossRef]

12. O'Kelly, M.; Collins, J.; O'Connor, P.; Stelfox, A.; Roche, G.; Hayes-McCoy, G. Three Promontory Forts in Co. Cork. Proc. R. Ir. Acad. C 1953, 55, 25-59.

13. Liversage, G. Excavations at Dalkey Island, Co. Dublin, 1956-1959. Proc. R. Ir. Acad. C 1968, 66, 53-233.

14. Proudfoot, V.; Wilson, B. Further Excavations at Larrybane Promontory Fort, Co. Antrim. Ulst. J. Archaeol. 1962, 24-25, 91-115.

15. Sidebotham, J. A Promontory fort on Tory Island. Ulst. J. Archaeol. 1949, 12, 98-103.

16. Barker, L.; Driver, T. Close to the Edge: New Perspectives on the Architecture, Function and Regional Geographies of the Coastal Promontory Forts of the Castlemartin Peninsula, South Pembrokeshire, Wales. Proc. Prehist. Soc. 2011, 77, 65-87. [CrossRef]

17. Cunliffe, B. Iron Age Communities in Britain; Routledge: London, UK, 1991.

18. Brooks, R. The Rumps: Second Interim Report on the 1965 Season. Corn. Archaeol. 1966, 5, 9-10.

19. Toolis, R. A Survey of the Promontory Forts of the North Solway Coast. Trans. J. Proc. Dumfries. Galloway Nat. Hist. Antiqu. Soc. 2003, 77, 37-78.

20. Cahill Wilson, J. Late Iron Age and Roman Ireland; Wordwell: Dublin, Ireland, 2014.

21. Barry, T.; Diarmond, S.; Shanley, T.; Scannell, M.; Soergel-Harbison, E. Archæological Excavations at Dunbeg Promontory Fort, County Kerry, 1977. Proc. R. Ir. Acad. C 1981, 81, 295-329.

22. Doyle, I. The Early Medieval Activity at Dalkey Island, Co. Dublin: A Re-Assessment. J. Ir. Archaeol. 1998, 9 , 89-103.

23. Horowitz, A. The effects of sea level rise of historic districts and the need for adaptation. In Master of Arts in Historic Preservation; Goucher College: Maryland, MD, USA, 2013.

24. Oyedotun, T. Shoreline Geometry: DSAS as a Tool for Historical Trend Analysis. In Geomorphological Techniques; Online Edition; Cook, S., Clarke, L., Nield, J., Eds.; British Society for Geomorphology: London, UK, 2014.

25. Ludlow, F. Three Hundred Years of Weather Extremes from the Annals of Connacht. J. Postgrad. Res. 2006, 5, 46-65.

26. Meere, P.; MacCarthy, I.; Reavy, J.; Allen, A.; Higgs, K. Geology of Ireland: A Field Guide; The Collins Press: Cork, Ireland, 2013.

27. Willson, W.; Du Noyer, G. Geological Survey of Ireland Sheet 179 Tramore; Ordnance Survey Office: Dublin, Ireland, 1901.

28. Parkes, M.; Meehan, R.; Préteseille, S. Corries, Caves and Coast.: The Geological Heritage of County Waterford; County Council: Waterford, Ireland, 2013.

29. Walsh, S. A Summary of Climate Averages for Ireland 1981-2010; Climatological Note No. 14; METéirann: Dublin, Ireland, 2012.

30. Westropp, T. The Promontory Forts and Traditions of the Beare and Bantry, Co. Cork. J. R. Soc. Antiq. Ir. 1920, 10, 140-159.

31. Power, P. The "Rian BóA Phádruig" (The Ancient Highway of the Decies). J. R. Soc. Antiq. Ir. 1905, 35, 110-129.

32. Manning, C. A Promontory Fort and Ogham Stone at Knockmahon, County Waterford. Decies 1989, 30, 7-11.

33. The Ex-Classics Web Site. Available online: http://www.exclassics.com (accessed on 4 May 2020).

34. Westropp, T. Fortified headlands and castles on the south coast of Munster: Part II, from Ardmore to Dunmore, Co. Waterford. Proc. R. Ir. Acad. C. 1914, 32, 188-227.

35. Cowman, D. Bronze-Age Copper-Mines at Dane's Island. Decies. 1982, 20, $22-27$.

36. Kelly, A. The discovery of Phocaean Red Slip Ware (PRSW) Form 3 and Bii ware (LR1 amphorae) on sites in Ireland-an analysis within a broader framework. Proc. R. Ir. Acad. C. 2010, 110, 35-88. [CrossRef]

37. Power, P. On an ancient (prehistoric?) copper ingot from Bonmahon. J. Waterf. South. East. Ir. Archaeol. Soc. $1909,12,86-89$. 
38. Cowman, D. Thomas ("Bullocks") Wyse: A Catholic Industrialist during the Penal Laws, I. Decies. 1983, 24, 8-13.

39. Du Noyer, G. Explanation to Accompany Sheets 167, 168, 178, and 179 of the Maps and Sheet 13 of the Longitundinal Sections of the Geological Survey of Ireland Illustrating Parts of the Counties of Waterford, Wexford, Kilkenny and Tipperary; Hodges, Smoth and Co.: Dublin, Ireland, 1865.

40. O'Brien, W. Mount Gabriel: Bronze Age Mining in Ireland; University Press: Galway, Ireland, 1994.

41. Westropp, T. Notes on certain promontory forts in the counties of Waterford and Wexford. J. R. Soc. Antiq. Ir. 1906, 36, 239-258.

42. Power, P. The Place-Names of the Decies; Blackwell Ltd.: Oxford, UK, 1952.

43. Casey, M. The Coastal Promontory Forts of Ireland. Unpublished; Interim Report for the Heritage Council held in the National Monument Service Archive Unit.

44. Mulholland, J. The Vanishing Medieval Settlements of Templeyvrick. Decies 1976, 2, 5-8.

45. O'Donovan, J. Ordnance Survey Letters: Waterford. 1841. Available online: http://www.askaboutireland. ie/reading-room/digital-book-collection/digital-books-by-subject/ordnance-survey-of-irelan/ (accessed on 17 July 2020).

46. The Down Survey of Ireland. Available online: http://downsurvey.tcd.ie/down-survey-maps.php\#c= Waterford (accessed on 4 May 2020).

47. Kaya, S.; Sertel, E.; Seker, D.; Tanik, A. Multi-Temporal Analysis and Mapping of Coastal Erosion Caused by Open-Mining Areas. Environ. Forensics 2008, 9, 271-276. [CrossRef]

48. Pollard, E. The Mesolithic Maritime Landscape on the North Coast of Ireland. Int. J. Nautical Archaeol. 2011, 40, 387-403. [CrossRef]

(C) 2020 by the authors. Licensee MDPI, Basel, Switzerland. This article is an open access article distributed under the terms and conditions of the Creative Commons Attribution (CC BY) license (http://creativecommons.org/licenses/by/4.0/). 